\title{
Clarion and Crystal-Clear Cell Hidradenoma
}

\author{
Anubha Bajaj* \\ Department of Diagnostics, Punjab University, India
}

Submission: March 07, 2019; Published: April 08, 2019

*Corresponding author: Anubha Bajaj, Department of Pathology, Punjab University, Chandigarh, India

\section{Preface}

Nodular or clear cell hidradenoma denotes an asymptomatic, exceptional, gradually progressive, benign, solid or cystic, intradermal adnexal neoplasm of sweat gland origin with eccrine or apocrine differentiation. Initially scripted by Mayer in 1941, the tumefaction describes with a dual subtype as hidradenoma with eccrine or period differentiation and hidradenoma with apocrine or clear cell differentiation [1]. Frequent betwixt fourth and eight-decade, peak incidence of the disorder is cogitated within sixth decade although clear cell hidradenoma can appear in the first decade. Of undetermined genesis, the cutaneous neoplasm arises from eccrine dermal adnexal glands although apocrine derivation is occasionally delineated. Clear cell hidradenoma or the nodular hidradenoma is a frequent histological subtype. The nomenclature includes captions such as eccrine acrospiroma, solid-cystic hidradenoma, clear cell acrospiroma, clear cell myoepithelioma, eccrine sweat gland adenoma, nodular hidradenoma, clear cell hidradenoma, cystic nodule hidradenoma, and eccrine acrospiroma.

\section{Disease Characteristics}

Eccrine acrospiroma elucidates as a solitary, firm, nodule with a preferable localization in the head and neck, face and upper extremities although lesions can be cogitated on the chest, shoulder, upper torso, upper or lower extremities. A female to male ratio of $1.7: 1$ and a mean age of presentation at 37.2 years is exemplified. An estimated proportion of lesions are cogitated at the head (30.3\%), upper limb (25.8\%) and trunk (20.2\%) [2,3]. Paediatric adnexal tumours demonstrate a predominantly follicular or apocrine/ eccrine genesis. Pilomatrixoma is a frequent and most encountered skin adnexal tumefaction situated in head and neck region. Tumours with sebaceous differentiation are distinctly infrequent. Hidradenoma is generally elucidated betwixt 20 to 50 years of age. Clear cell hidradenoma can occur as a polypoidal umbilical mass, congenital neck swelling or as axillary nodules in infants. Hidradenoma emerge as a gradually progressive, solitary, asymptomatic, firm, mobile tumefaction or nodule [3,4]. A few of the tumour nodules can demonstrate a serous effluvium or may ulcerate. No anatomical site is exempt from the appearance of the tumour. Lesions are disclosed in vulva in females, peri-anal region in males, scalp, head and neck, face, lower eyelid, external auditory canal, knee and foot. The tumefaction can be associated with hyper-oestrogenaemia as oestrogen and progesterone receptors are discerned on the tumour cells. Hyper-oestrogenaemia can engender multitudinous lesions at various sites $[4,5]$.

\section{Clinical Elucidation}

Tumefaction of hidradenoma appears as solitary or multiple lesions. A female preponderance is noted with implication of middle-aged individuals. Adult females can exhibit lesions confined to the vulva. Although the disorder is predominantly cogitated in adults, nodular hidradenoma can arise in children. The nodules are frequently asymptomatic, evolve gradually and rarely demonstrate clinical symptoms such as pain and serous discharge. Solid or cystic, well demarcated, asymptomatic, minimally progressive, endophytic, rarely exophytic nodules of varying magnitude are cogitated usually of dimension betwixt 0.5 centimetres to 3.0 centimetres. The tumefaction enunciates a minimal possibility of malignant transformation and probable ulceration. The generally solitary nodules are skin coloured or crimson and frequently elucidated on the scalp, face, thorax, abdomen and proximal extremities [5,6]. Unconventional clinical appearance is cogently described with tumours exceeding 3 centimetres in diameter, erosion of the superficial surface, a preponderant cystic component and aberrant locations such as the plantar region.

\section{Histological Elucidation}

Clear cell hidradenoma is a well circumscribed, unencapsulated tumour as delineated on gross and morphological examination. Clear cell hidradenoma comprises of lobules of tumour cells situated in the dermis with extensions into subcutaneous fat. The tumefaction is segregated from the epidermis by a dormant Grenz zone. The neoplasm, characteristically confined to the upper dermis, demonstrates a congregation of dual population of miniscule or enlarged, monomorphic or polyhedral epithelial cells with copious clear or eosinophilic cytoplasm and miniature nuclei [6,7]. The dimorphic cell population elucidates polygonal cells with abundant glycogen thereby inducing a clear appearance to the 
cytoplasm admixed with elongated, darkly stained, miniature cells cogitated at the periphery.

Clear cell metamorphosis and/or squamous metaplasia can be a predominant feature within the tumour cell accumulates. Focal apocrine elements are evidently displayed. The tumour exhibits diverse composites and nodules of benign epithelial cells articulating miniscule ductules and duct lumina generally cogitated within the upper dermis. Duct like configurations recapitulate the eccrine ducts. Additionally, slit like spaces lined by concentric layer of squamous epithelial cells are exemplified. Numerous cystic spaces are elucidated on account of tumour cell degeneration. Apocrine secretion can be delineated within the ductular lumen due to decapitation of cytoplasmic vacuoles $[7,8]$. Squamous, sebaceous or mucinous epithelial differentiation can be enunciated in specific lesions. The cellular component is variable, although clear cell predominance emerges in proportionately one third instances. Distinctive lesions are enveloped in an intact dermal integument or can demonstrate focal and superficial ulceration with discharge of serous fluid. The tumefaction exhibits singularly solid or cystic elements or an admixture of solid and cystic components in varying proportions or a clear cell predominance. Solid areas enunciate epithelial lobules comprised of preponderant polyhedral cells with a basophilic cytoplasm and clear cells with glycogen containing cells with a clear cytoplasm. Clear cells contain glycogen or a diastase resistant substance which stains with periodic acid Schiff's (PAS) reagent. Lipid vacuoles are not elucidated.

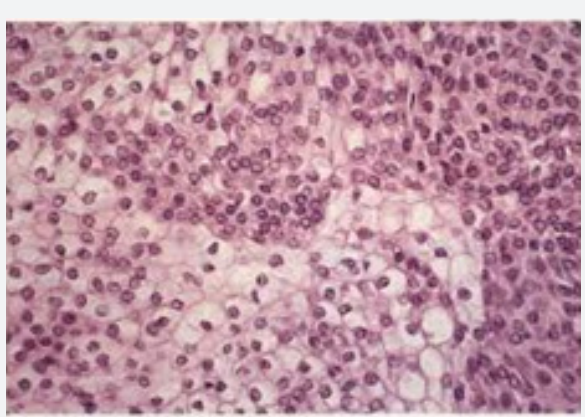

Figure 1: Hidradenoma with predominant clear cells and polyhedral cells (JAMA Network).

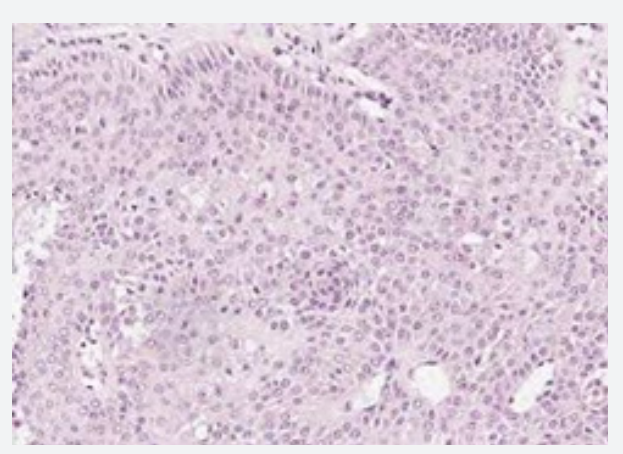

Figure 2: Hidradenoma composed of prominent clear cells and miniscule nuclei (Synapse Koreamed).
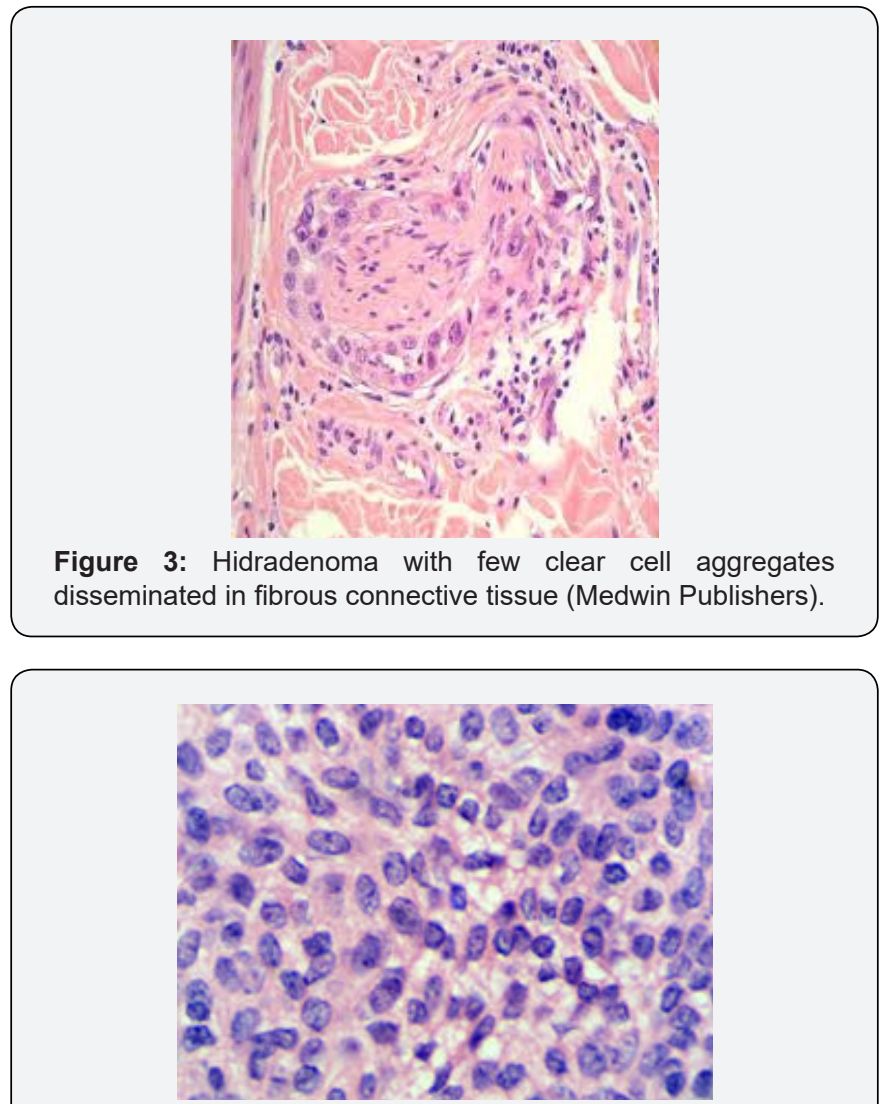

Figure 4: Hidradenoma -nodules of clear cells with miniscule, monomorphic nuclei (Flickr.com).

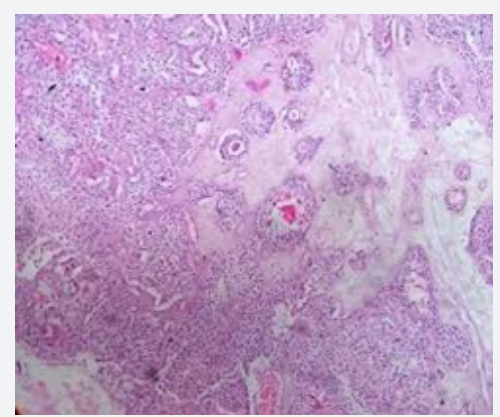

Figure 5: Hidradenoma - solid-cystic variant with a bimodal cell population (IOSR Journals).

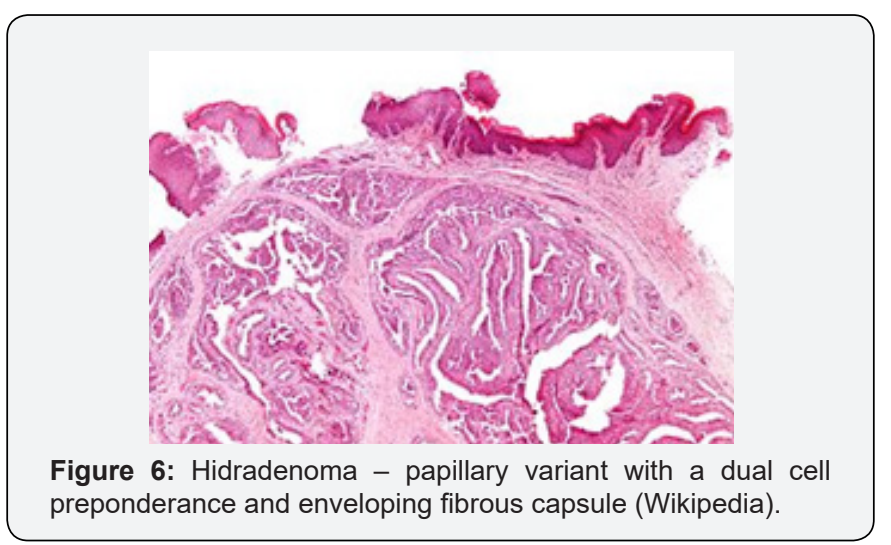




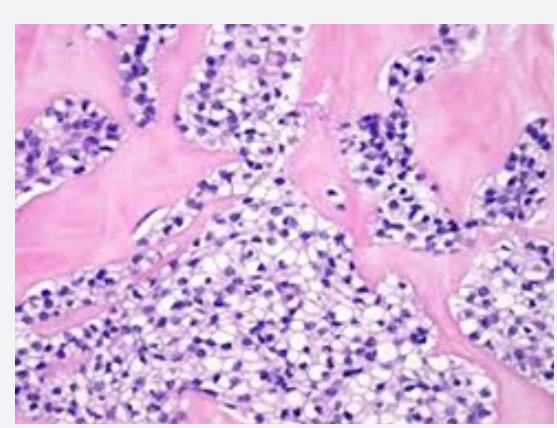

Figure 7: Hidradenoma-distinctive clear cells, monomorphous nuclei and fibrous circumscription (Twitter).

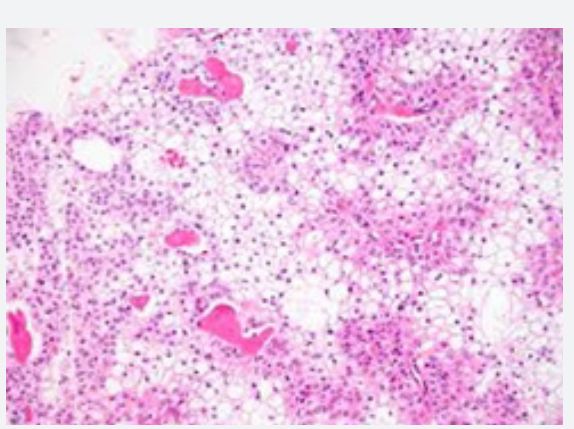

Figure 8: Hidradenoma - clear cells filled with glycogen and interspersed polyhedral cells (Radiopedia).

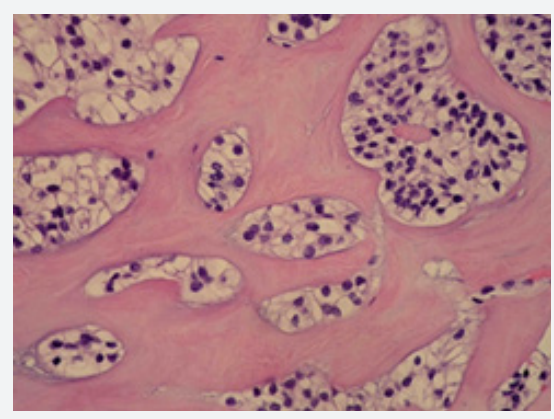

Figure 9: Hidradenoma - clear cells, uniform nuclei and fibrous embedding (Bosnian Pathology).

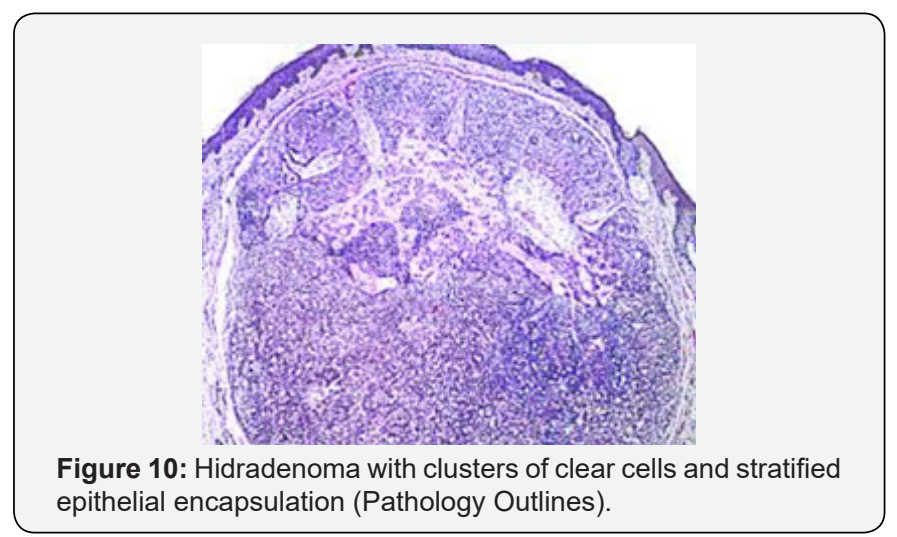

Clear cells denote a metabolic variant of epidermoid cells, rather than an aberrant category of tumour differentiation. Stroma intervening within the lobules enunciate delicate, vascularised cords of fibrous tissue or dense hyalinised tissue. Myxoid and chondroid stroma are infrequent. Exophytic growth with superficial surface erosion of the tumour is observed $[8,9]$. As the histological description and annotation is competent, confirmation with immune histochemistry is not a cogent, essential exercise. Malignant transformation is infrequent and is characterized by morphological parameters such as nuclear atypia, necrosis and atypical mitosis. A distinctive histological enunciation may not accurately predict the clinical behaviour of clear cell hidradenoma (Figure 1-14).

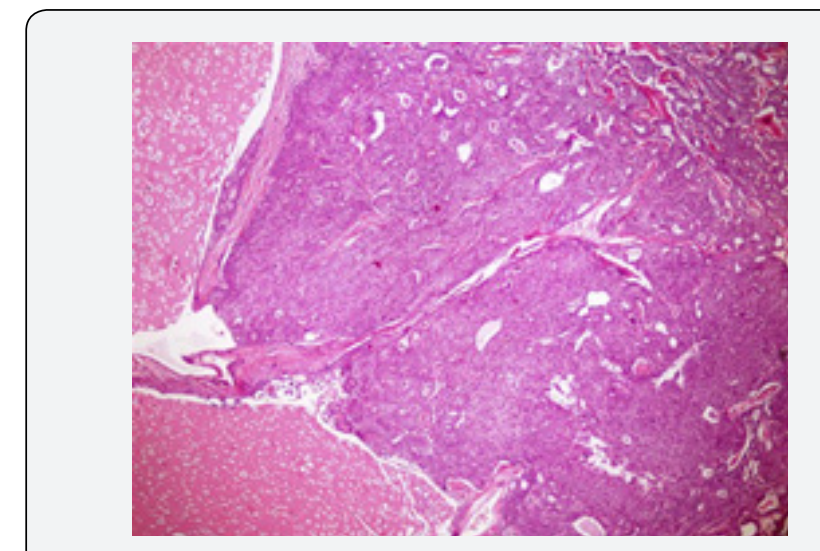

Figure 11: Hidradenoma with moderate clear cell clumps and eosinophilic, polyhedral cells (Pathology Outlines).

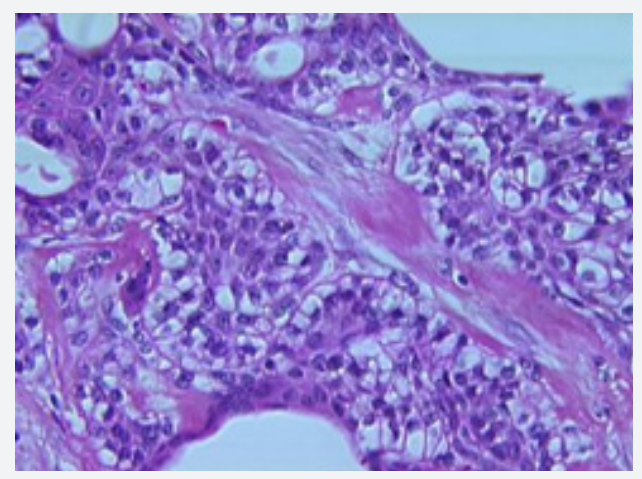

Figure 12: Hidradenoma- clear cell aggregates, small nuclei and a fibrous stalk (Dx path).

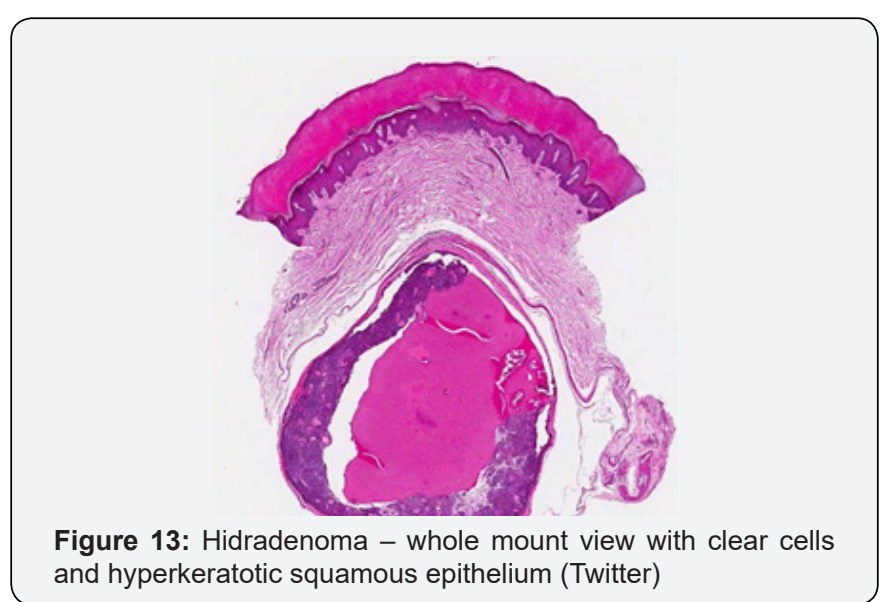




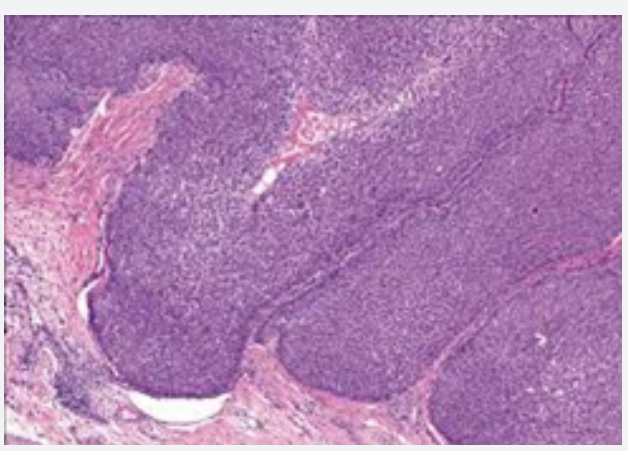

Figure 14: Nodular hidradenoma with malignant ingress of atypia, mitosis and infiltrative margins (Middle East African $\mathrm{J}$ of Opthalmology).

\section{Distinguishing Diagnosis}

Clear cell hidradenoma necessitates a distinction from a concordant lesion such as haemangioma, glomus tumour, cutaneous lymphoma, dermatofibrosarcoma protuberans, leiomyoma, follicular cyst, trichilemmoma or adjunctive sweat gland or adnexal tumours which are clinically indistinguishable $[9,10]$. Clear cell neoplasm confined to the dermis necessitate a segregation from metastatic malignancies and primary skin tumours with follicular, sebaceous and sweat gland differentiation. Clear cell hidradenoma in adults require a demarcation from metastatic renal cell carcinoma. However, nodules of hidradenoma are devoid of the classic pulsating vascular prominence as delineated in malignant deposits of renal cell carcinoma $[10,11]$. Although clear cell hidradenoma, also termed as eccrine acrospiroma, is predominantly a benign neoplasm, the nodules can be subjected to malignant transformation. Engendered malignancy is cogitated as "clear cell hidradenocarcinoma" or "malignant clear cell hidradenoma". The malignant counterpart is an exceptional neoplasm and is characterized by an infiltrative tumour perimeter, cellular atypia and innumerable atypical mitosis $[11,12]$.

\section{Therapeutic Options}

A comprehensive surgical extermination is a pre-requisite in managing clear cell hidradenoma as the nodules are endowed with an enhanced potential of tumour recurrence. A wide tumour perimeter on surgical excision is mandated for a detailed histological confirmation which ensures minimal probable reoccurrence and evaluating prospective malignant transformation. A surgical eradication of the neoplasm with a broad perimeter is the preferred therapy. Malignant transformation is infrequent although neoplasm such as clear cell hidradenocarcinoma tend to reappear. Tumefaction undergoing malignant conversion demonstrate an aggressive clinical course, disseminated disease with adjuvant, enhanced mortality $[12,13]$.

\section{References}

1. Mayer I (1941) Zur histologie der hidroadenome. Frankfurter Zeit $f$ Pathol 55: 548-580.

2. Kataria SP, Singh G (2018) Nodular hidradenoma- a series of five cases in male subjects and review of literature. Adv Cytol Pathol 3(2): 46-47.

3. Sathe PA, Baste BD (2018) Nodular Hidradenoma- a rare tumour in children. Indian J Child Health 5(8): 549-550.

4. Gonul M, Cakmak SK (2010) A skin tumour in a young girl. Indian J Dermatol Venerol Leprol 76(4): 445-446.

5. Kim JM, Kim SH (2015) Axillary nodular hidradenoma in a 29-monthold girl. J Korean Asso of Paediatr Surg 21(1): 11-13.

6. Sousa VB, Lacerda VC, D Elia MLN (2018) Clear cell hidradenoma-atypical presentation on the scalp. Surg Cosmet Dermatol 8(4): 570-572.

7. Dubhashi SP, Sindhwani RD (2014) Nodular hidradenoma over the chin: a rare presentation. Int J Health and Allied Sci 3(4): 248-250.

8. Gatti A, Di Meo N (2010) Dermoscopy of eccrine acrospiroma masquerading as nodular malignant melanoma. Acta Dermatovenerol Alp Pannonica Adriat 19(4): 23-25.

9. Pushpa B, Duraisamy K (2015) Study on Morphological Features of Nodular Hiadradenoma. Journal of Evolution of Medical and Dental Sciences 4: 9140-9144.

10. Das A, Gayen T (2016) A weeping tumour in a young girl: an unusual presentation of nodular hidradenoma. Indian J Dermatol 61(3): 321323.

11. Jlalia Z, Bahroun S (2017) Giant hidraadenoma of the limbs: a report of two paediatric cases. J Orthop Oncol 3: 1-4.

12. Ireland AM, Harvey NT (2017) Paediatric cutaneous adnexal tumours: a study of 559 cases Pathology 49(1): 50-54.

13. Shin HT (2014) Clear cell hidradenoma on the palm. Ann Dermatol 26(3): 403-404.

\section{Your next submission with Juniper Publishers} will reach you the below assets
- Quality Editorial service

- Swift Peer Review

- Reprints availability

- E-prints Service

- Manuscript Podcast for convenient understanding

- Global attainment for your research

- Manuscript accessibility in different formats ( Pdf, E-pub, Full Text, Audio)

- Unceasing customer service

Track the below URL for one-step submission https://juniperpublishers.com/online-submission.php 